Article

\title{
New Urbanism as Urban Political Development: Racial Geographies of 'Intercurrence' across Greater Seattle
}

\author{
Yonn Dierwechter \\ School of Urban Studies, University of Washington, Tacoma, WA 98402, USA; E-Mail: yonn@uw.edu
}

Submitted: 12 June 2020 | Accepted: 15 October 2020 | Published: 22 December 2020

\begin{abstract}
While New Urbanism is now subject to a range of theorizations from different perspectives and disciplinary approaches, it is rarely framed as part of a society's overall political development. This article explores New Urbanism through recently 'cosmopolitanized' and 'urbanized' theories of American Political Development (APD). For many years, APD scholars like Skowronek and Orren have emphasized the conceptual importance of 'intercurrence,' which refers to the simultaneous operation of multiple political orders in specific places and thus to the tensions and abrasions between these orders as explanations for change. Urban scholars have engaged with these ideas for some time, particularly in studies of urban politics and policy regimes, but APD's influence on urban planning theory and practice remains underdeveloped. This article takes up this lacuna, applying select APD ideas, notably intercurrence, to understand how multi-scalar governments develop space though New Urbanist theories of place-making, with special attention paid to race. Examples from metropolitan Seattle are used to illustrate (if not fully elaborate) the article's overall arguments and themes.
\end{abstract}

\section{Keywords}

APD; intercurrence; New Urbanism; planning theory; race; Seattle; sustainability; urban political development

\section{Issue}

This article is part of the issue "New Urbanism: From Exception to Norm-The Evolution of a Global Movement" edited by Susan Moore (University College London, UK) and Dan Trudeau (Macalester College, USA).

(C) 2020 by the author; licensee Cogitatio (Lisbon, Portugal). This article is licensed under a Creative Commons Attribution 4.0 International License (CC BY).

\section{Introduction}

From the vantage point of the early 2020s, New Urbanism represents a shift in local planning practice and planning theory after its introduction into North American communities in the late 20th century (Talen, 2000). As the other articles in this thematic issue also make clear, the adoption of New Urbanism in societies outside of North America only amplifies this opening claim (see for example, MacLeod, 2013; Murray, 2013). By the turn of the millennium, Susan Fainstein (2000) had identified this movement as one of three leading frameworks for contemporary spatial planning practice, along with communicative rationality and what she called a more radical "just city" model. Arguably, New Urbanism has been the most influential of these three major planning theories thus far-rightly or wrongly, for good or for bad (Dierwechter \& Coffey, 2017; Moore, 2010).
As a set of normative assertions, New Urbanism is less explicitly concerned with planning proceduresrational-comprehensive, advocacy, transactive, equity, radical, communicative, etc. Originating in the design arts rather than social sciences, law, neighborhood activism, large-scale data modeling, or community development, New Urbanism instead returns the 'city' to city planning. It celebrates urban form discourses largely eclipsed in planning studies after the strong social science turn in the 1960s. This assertive revival of form ideals captured and to a large extent captivated a North American audience increasingly repelled by formless urban sprawl and the ancillary dysfunction of automotive modernism as much as any urban discourse had managed to do for many decades (Dierwechter, 2017; Grant, 2006). Offering physical renderings of the future more than recommendations for improved process, New Urbanism soon traveled far and wide, includ- 
ing high profile developments within major cities such as Garrison Woods in Calgary, Alberta, Canada (Figure 1).

Popular success attracted scholarly attention from all sides. The Marxist geographer David Harvey (1997) criticized New Urbanism as privileging spatial forms over social processes. The libertarian writer Randal O'Toole (2007) imagined New Urbanism as trying to engineer society through collectivist planning rather than free markets. Still others simply saw New Urbanism as overly nostalgic, insufficiently innovative, or especially prone to superficial imitation (for a useful review see Rees, 2017). Scholarly defenders nonetheless pushed back (Talen \& Ellis, 2002) and New Urbanism trundled along, projectby-project, in everyday planning administration and practice. Decades later, New Urbanism is not 'new.' It is now a normal part of North America's landscapes of living, working, and moving-jostling with inherited configurations of Victorian era and modernist urbanisms no less than nascent developments in city-building like 'smart cities' that resist these categories (Herrschel \& Dierwechter, 2018).

A vast literature on New Urbanism's impacts has documented its perceived successes and failures in pragmatic implementation in different regions and communitiesmuch like earlier work had done for, inter alia, the City Beautiful Movement, garden suburbs, regionalism, comprehensive planning, modernism, advocacy, and equity planning (Crane, 1996; De Villiers, 1997; Deitrick \& Ellis, 2004; Dierwechter, 2014; Dierwechter, 2017; Ellis, 2002; Garde, 2004; Grant, 2006, 2007; Harvey, 1997; Larsen, 2005; MacLeod, 2013; Mitchell, 2002; Murray, 2013; St. Antoine, 2007; Steuteville, 2008; Talen, 2000, 2005; Trudeau, 2013a, 2013b; Trudeau \& Molloy, 2011).
New Urbanism, particularly when coupled with the closely associated concept of Smart Growth (Knaap \& Talen, 2005), is now subject to a range of theorizations from different perspectives and disciplinary approaches. However, it is rarely interpreted as part of a society's political development and institutional maturation (though see Dierwechter, 2017). This raises a number of key questions of special interest here: How and why do governing institutions engage, promote, and/or resist New Urbanist rationalities and policy agendas and, therefore, what are the socio-spatial consequences of these diverse engagements? Taken together, in other words, do diverse governing institutions committed to New Urbanism produce spaces of what I shall call below 'reinforcement' or 'transformation'?

To address these questions, I deploy 'cosmopolitanized' and 'urbanized' theories of American Political Development (APD), a neo-Weberian branch of historical institutionalism associated with scholars of politics like Steve Skowronek and Karen Orren (2004). APD researchers have emphasized the overarching concept of 'intercurrence,' which refers in broad terms to how the simultaneous operation of multiple political orders in specific places (or sites) generates tensions and abrasions that occasion change. Skowronek and Orren (2004) see these changes as durable shifts in governing authority. Urban scholars have engaged with these ideas for some time, particularly in studies of urban politics and policy regimes, and have thus developed a more cosmopolitan urban political development (UPD) variant for cities in the US, Canada, Australia, and the UK (see e.g., Hodos, 2009, for a key British application). APD/UPD's influence on urban planning theory and prac-

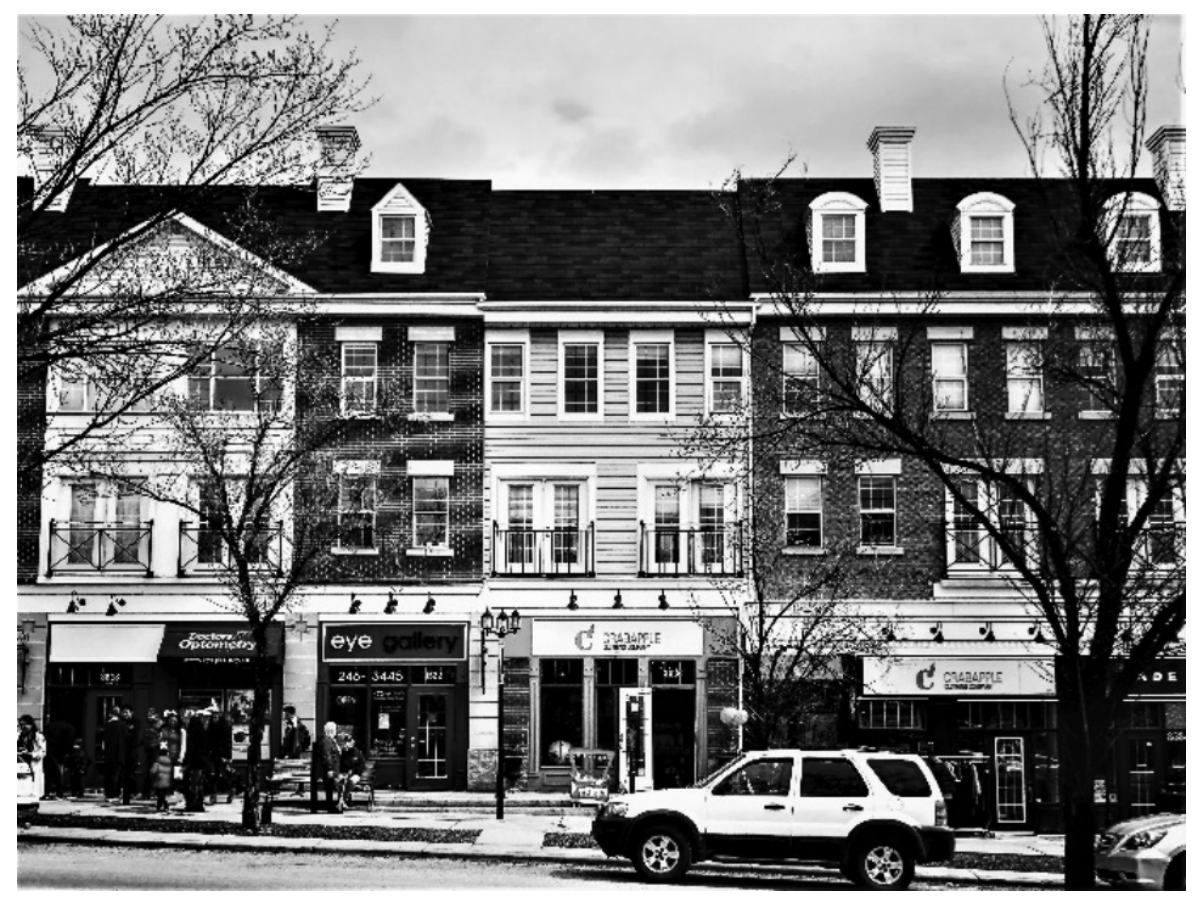

Figure 1. New Urbanism as neo-traditional vertical mixed use: Garrison Woods in Calgary, Alberta, Canada, in April 2019. Source: Author. 
tice remains embryonic, although Dilworth and Weaver (2020) provide a recent review of how ideas in general shape UPD in comparative perspective, including its effects on urban planning inside and beyond the US.

This article takes up the APD challenge for planning studies. I apply select theoretical concepts-notably intercurrence-to understand how multi-scalar and multi-departmental governments develop metropolitan space though New Urbanist practices of place-making. After an initial examination of New Urbanism as A/UPD in the next section, I present examples from Greater Seattle to illustrate the article's arguments and themes, focusing especially on how race and institutions shape these changes. Methodologically, the article reflects several site visits in recent years by the author; an analysis of census data on social and economic dynamics; and a review of relevant planning documents and reports both by municipalities and consultants. Drawing on these data, mini-case studies aim to illustrate the diverse territorial outcomes associated with New Urbanism in practice. A concluding section recapitulates the article's main themes and considers ongoing research question for further exploration by planning scholars.

\section{New Urbanism as Urban Political Development}

A now well-known normative theory of urban design and 'neo-traditional' place-making, various researchers have also considered New Urbanism as a "counterproject to post-industrialization" (Durham-Jones, 2000); "new modernist movement" (Vanderbeek \& Irazábal, 2007); solution to "distressed inner-city neighborhoods" (Larsen, 2005); "factor in the mobility of the elderly" (Hoyland, 2003); "gated community" (Grant, 2007); "quandary of post-public space" (Murray, 2013); and "sustainable development" (Trudeau, 2013a).

Solution, factor, place, community, space, culture, movement. And perhaps not least, an emerging urban form for the pragmatic implementation of sustainable development-albeit contingently and with disparate implications from place to place, for different groups of people, at different times. 'Neo-traditional' forms refer to pre-automotive place-making principles that include inter alia: mixed land uses; a clear 'center' with both private and iconic public amenities (schools, libraries, court houses); diverse mobility options; compact, walkable, tree-lined streets; and houses with minimal setbacks (Hooper, Foster, Knuiman, \& Giles-Corti, 2018). When these principles support regional transit investments, such as light rail lines, they also merge with concepts like Transit-Oriented Development (TOD). "New Urbanism is associated with sustainable behaviors, such as walking and social interaction[,]" Trudeau (2013a, p. 443, emphasis added) carefully concludes, "[h]owever, the contexts in which these associations operate are clearly more limited than what proponents of the movement expect." One major context is class composition; another is race, which is of particular interest in what fol- lows (Dierwechter, 2014). The conscious design of places through planning processes and techniques therefore matters for marginally improving many reasonable urban metrics for social and environmental sustainability, but only as one of several urban conditions that reflect more complex, deeper spatialities and temporalities of urban development and societal change.

These different perspectives suggest that theories for New Urbanism are, therefore, not that same thing as theorizing the spaces that New Urbanism 'makes' or 'unmakes.' Put more productively, New Urbanism-like Smart Growth-does not aim to explain itself. Smart Growth focuses mostly on laws and policies that attack low-density residential subdivisions and concomitantly encourage more compact, contiguous, and coordinated development patterns; more detailed and architecturally prescriptive, New Urbanism instead focuses on the design intricacies of "pedestrian-oriented...urban life" (Kushner, 2003, p. 45). Both give practitioners a framework for normative action and long-term guidance, which I take to be one of the important purposes of planning theory. Theories for planning action, however, are not the same as theories of planning in action. Planning confronts a world of prior construction, even in greenfield sites, which is what I am mainly interested in here. In the US, and elsewhere too of course, race is always one of the most important 'prior' factors to consider.

A generation ago, Oren Yiftachel (1989, p. 23) noted that "technical-neutral orientations" for planning theory-whether focused on 'urban form' (like New Urbanism and La Ville Radieuse) or indeed "procedural debates" (like comprehensive rationality and bounded incrementalism)-would increasingly compete for scholarly attention with "openly politicised approaches." For Yiftachel (1989), and for me in this article, such competition need not generate sectarian camps poised for zero-sum intellectual warfare, despite obvious and important differences. It might instead help to facilitate wider-reaching interrogations of different approaches to understanding what planning is actually about-and thus what planning does in and to cities and metropolitan regions. How might we understand the geographical impacts of theories such as New Urbanism for planning in key city-regions like Greater Seattle?

Examples of more politicised approaches, which Yiftachel (1989) also calls "analytical," include Marxian and Foucauldian treatments of city planning as a component of industrial and post-industrial urbanization strategies in differently ordered political economies. Richard Foglesong (1986), for instance, explained the relative absence of social housing in US planning visions in terms of the comparatively weak political influence of America's labor movement on the multi-scaled state; this reflected the even deeper impact of racial tensions and social heterogeneity in the US than in, say, Sweden, Holland, or even neighboring Canada (and see Marks \& Lipset [2000]). Bent Flyvbjerg (1998), in turn, used Foucauldian social theory to remap city plan- 
ning's self-stated search for comprehensive rationality in social-democratic, civic-minded Aalborg, Denmark as, in his view, the rationalization of power, memorably arguing that power concerns itself with defining reality rather than with discovering what reality 'really' is. Applied to New Urbanism, neotraditional developments are, following Foglesong (1986) and other scholars (Harvey, 1997) , a spatial form to facilitate the circulation of capital, and/or, with Flyvbjerg (1998), how postmetropolitan communities shape urban space in order to rationalize relationships of uneven power, whether class-dominated or organized around other social axes like race, gender, and sexuality that are typically prominant themes in much post-structuralist work.

From the 1970s on, Marxian/structural and then Foucauldian/post-structural frameworks largely sidelined a third type of 'analytical' planning theory associated with 'Weberian' approaches that had interrogated the state's relatively autonomous role in urban development. Gurr and King (1987), for instance, noted that community power games or regime-building coalitions do not really dent the local state's interest in autonomy from national governments. The seminal work in planning studies remains Ray Pahl's (1970) collection of essays on post-war British planning, Whose City? Pahl (1970) explored how urban "gatekeepers," notably planners, shaped the allocation of housing and other amenities. Though dated by the tsunamis of globalization, privatization, and financialization in recent decades, Pahl's (1970) empirical concerns remain relevant: residential sprawl, designed containment, and in situ class tensions between locals and newcomers on the metropolitan fringe. Moreover, as Forrest and Wissink (2017, p. 163) have suggested, his neo-Weberian focus on the "urban managerial agenda" of gatekeepers is actually more important than ever "if we want to expose issues of power and inequality."

Pahl's original work merged with radical critiques in the 1970s. Neo-Weberian scholarship from the 1980s continually sought to "bring the state back in" (Evans, Rueschemeyer, \& Skocpol, 1985). One strain of historical institutionalism became known as the APD approach (Valelly et al., 2016). Central to APD are three key concepts of relevance here, at least when suitably cosmopolitanized and urbanized: 'political time,' 'multiple orders,' and 'intercurrence.' In APD, time does not simply 'pass' or act uniformily to frame events. Time matters for how political institutions develop through the sequencing of ideas and reforms. Rather than a singular time-an abstract chronological 'history'-APD treats political time as temporally uneven. Some political institutions are 'ancient' and remarkably durable (such as British common law); others are much more recent in development (like digital sharing protocols). Yet they typically interact at sites in ways that shape society as much as as society shapes them (the 'Weberian' effect). Through path-dependencies, particular 'orders,' or constellations of rules, practices, institutions, and ideas that hold together over time, project themselves forward and insinuate themselves into new controversies.

Change occurs, APD theorists claim, "to alleviate tensions that are routinely introduced by the simultaneous operation, or intercurrence, of different political orders" (Skowronek \& Orren, 2004, p. 17). 'Intercurrence'defined more simply here as multiple orders-in-actionleads to durable shifts in governing regimes, albeit not always smoothly nor completely, and often in ways that suggest a syncretic admixture of ideas and practices. Accordingly, intercurrence is easily the most important concept in APD studies because it describes the circumstances under which political development happens. Here is an example of 'politics in time' and 'multiple orders' within the US, again also highlighting the importance of race as an central challege:

In the 1830s the coexistence of southern slavery with an expanding democracy for white male citizens [is] evidence that any realistic depiction of politics in time will include multiple orders, as well as the conflict and irresolution built into their reciprocal interactions. At every point in antebellum America, politics was framed by the competing entailments and mutually threatening movements of these two orders along their different paths. (Skowronek \& Orren, 2004, p. 17, emphasis added)

In recent years, a few scholars of urban politics have grown interested in urbanizing and/or de-Americanizing APD (Dilworth, 2009; Rast, 2015; Stone, 2015). This work builds on arguments by Ira Katznelson, Amy Bridges, and Steven Erie. Jack Lucas (2017), for example, has explored the application of concepts like intercurrence to understand the development and maturation of political authority in different urban policy domains of Canadian cities. He discusses 'multiple orders' over political space and political time and links these to questions of change in urban Canada. Also using the core concept of intercurrence, Richardson Dilworth (2016) has argued that the "uneasy fit" of cities within the American political system makes them significant in understanding APD more generally. Dilworth's coedited book with Timothy Weaver attempts to consolidate the urbanization and cosmopolitanizaton of APD's approaches, focusing on how "ideas" shape "urban political development" choices not only within the US but in many other countries. Chapters on India, Chile, and South Africa suggest APD's cosmopolitan promise (Dilworth \& Weaver, 2020).

So far, though, little APD work has spilled into wider urban planning scholarship (though see Dierwechter, 2013). Inspired by authors like Smith (1993), Skowronek and Orren (2004), and especially King and Smith (2005) as well as Lucas (2017), Rast (2015), and Dilworth (2009), my own extended treatment of Smart Growth across Greater Seattle attempted to explain new geographies of contemporary urban planning for urban sustainability as the 'competing entailments' or 'intercurence' of three 
political orders built at different times in the region's political and policy history: namely, a market-liberal order; a state-progressive order; and a radical-society order (Dierwechter, 2017). Smart Growth, I argued, was not simply about the spatialized march of neoliberalism, nor, as others suggest, a state-progressive project to curb costly sprawl, nor even the institutionalization of a single racial order, but a set of uneven geographies of intercurrence, wherein all three interacted at specific sites to shape the actually-existing, highly variegated, metropolitan space-economy of Greater Seattle.

New Urbanist geographies similarly require us to embed its effects within wider theories of urban change and societal transition. While the Marxian and Foucault approaches to planning scholarship just discussed are available, in what follows here I develop an urbanized APD (or UPD) approach that highlights how geographies of intercurrence-'multiple orders-in-action' that shape new planning spaces-might advance our understanding of Trudeau's concerns with the limitations imposed on New Urbanism by the 'contexts' in which they operate. Put more generally, I argue through a case study of spatial planning systems across Greater Seattle for seeing New Urbanism as a specific form of UPD. The resulting landscapes reflect inherited and new geographies of reinforcement and transformation, respectively, rather than a monocausal spatialization of capital accumulation, for instance, or the territorialization of a specific kind of subject formation and identity. In particular, I focus on contextualizing the profound influence of race in the American context, using Desmond King and Rogers Smith's (2005) specific concept of "racial institutional orders" to do so.

\section{Greater Seattle's New Urban(ist) Spaces of Intercurrence}

The Seattle city-region-Greater Seattle-is a major metropolitan area in the American Pacific Northwest made up of four million people and 80 major political entities, including King, Pierce, Snohomish and Kitsap counties, as well as cities, towns, ports, state and local transportation agencies, and tribal governments (Figure 2). Only about 750,000 people live in the city of Seattle; most of the region's population resides in a diverse array of suburbs, some more compact and job-rich than others (Dierwechter, 2020). Much like neighboring Portland, both the city of Seattle and the wider region are disproportionately white, especially when compared with cities like Los Angeles, Chicago, New York, or Miami. About $68 \%$ of Seattle is "white alone," according to the US Census Bureau (2018). The suburban municipality of Snoqualmie, in King County near Seattle and the New Urbanist home of Snoqualmie Ridge discussed below, is well over $80 \%$ white alone. In contrast, the suburban city of Dupont, located in Pierce County near the port city of Tacoma, and the home of a second major New Urbanist development,
Northwest Landing, also discussed below, is actually home to a larger African American population. Long shaped by the once-dominate Boeing hub-and-spoke industrial cluster (Gray, Golob, \& Markusen, 1996), globalized economic restructuring around the Microsoft-led IT boom of the 1980s and then the Amazon Corporation in the 1990s vastly accelerated low-density growth pressures across the entire city-region. This forced ongoing conversations about spatial planning and development control to the top of the state's political agenda.

\subsection{Toward New Ways of Managing New Urban Growth}

In 1989, the Washington City Planners Director Association (WCPDA) - frustrated and fatigued - issued a searing condemnation of the state's chaotic spatial planning institutions and growth management system. This condemnation perfectly illustrates how intercurrence works in practice:

Washington state's present system for planning is ad hoc, disjointed, and lacks a central vision. The laws governing land use and development are a patchwork enacted over the past century-a [state] constitution written to address the problems of the 1880 s, planning enabling statutes adopted in the 1930s and environmental always passed in the 1970 s....At the state level, agencies send uncoordinated, and even conflicting messages to local governments, the private sector, and the public. Each pursues a narrow and exclusive mandate on an independent schedule. (WCPDA, 1989, p. 4)

Ideally, planning provides communities at various scales with a range of complementary tools to (re)shape the material geographies of daily life. Planning promises consciously deliberated public oversight of the built and natural environments over long periods of regulatory time. In 1989, the WCPDA in essence called for a new system of comprehensive and coordinated planning to overcome the ad hoc, disjointed, narrow, fragmented system then governing the spaces of urban and rural change in Washington state. Put another way, the WCPDA called for the political development of spatial planning. In 1990/91, the state of Washington passed the landmark Growth Management Act (GMA). In 2020/21, three decades later, the GMA remains one of the few state-level spatial planning statutes in the US that appreciably reforms and actively directs local planning activities, particularly around strategic, longterm efforts to contain discontinuous sprawl through regionally-coordinated urban growth boundaries, concurrency provisions, critical areas protection, and mandatory comprehensive planning with required local policy elements like land-use, transportation, housing, and utilities (Dierwechter, 2008). That said, the GMA reflects its own 'multiple orders' of development, its own problems of intercurrence, its own 'competing entailments and mutually threatening movements.' 
Similar to how Widestrom (2011) interprets the US Federal government's Community Reinvestment Act (CRA), which dealt with redlining practices in the mortgage industry, Washington's GMA system undoubtedly also represents a durable shift in governing authority, i.e., the political development of city planning in this part of the US. Yet like the CRA, Washington's GMA projects upon local urban space the ongoing intercurrence of state-level institutions and ideas, which themselves reflect the awkward and uneven political geography of the state legislature. Like the CRA, in other words, the GMA specifically shows how "ordering mechanisms and pathways of development coexist, creating multiple ordering mechanisms and highly contingent politics...[and therefore...] how multiple ideas and ordering mechanisms matter for understanding policy creation and evolution" (Widestrom, 2011, p. 7). The GMA emerged in a world of prior construction and contended with institutional and ideational forces that worked against its full realization.

Not all counties in the state, for one thing, had to adopt GMA provisions, suggesting the state's "spatial selectivity" around growth (Jones, 1997). Euclidean zoning patterns based on the maligned development and design codes originally established the 1930s barely budged in many communities, even in the Seattle region, where growth pressures offered major opportunities for a considerable remaking of such codes (Robinson, Newell, \& Marzluff, 2005). Efforts to open up long-range planning discussions to more active participation and citizen inclusion after the tumultuous 1960s abutted and grated with the remarkable durability of comprehensive planning rationalities and, even deeper and older than that, ideological demands, thinly veiled or outwardly racist, that local planning's main 'job' was to defend single family homes from the presumed threats to property devaluation associated with mixed-class housing or non-residential uses. Despite years of scholarly attacks on the modernist "comprehensive model" of planning (Whittemore, 2015), it nonetheless formed in practice the core strategy for the GMA system (Puget Sound Regional Council, 2008). Still, the state-legislative mandate in Washington meant that local communitiesgeneral purpose municipalities and urbanized counties which service non-incorporated areas outside legal municipalities - now had to 'manage growth' with their adjacent neighbors in mind; moreover, state-organized goals like sprawl reduction, sustainable development, and affordable housing provided a normative framework or 'vision' that created a new intellectual space into which then ascendant 'form' theories like New Urbanism could receive public attention.

\subsection{Form Theories Face Contending Racial Orders}

From its inception, the GMA articulated broad development goals-or visions-that emphasized planning themes also prominent in the fast-emerging New
Urbanism movement, notably concentrated urban growth, sprawl reduction and historic preservation. New Urbanism furthermore offered local communities (and real estate developers) detailed ideas for how to concentrate urban growth, reduce sprawl, and preserve historic buildings and neighborhoods. As parallel discourses of Smart Growth took off in the-1990s, new spatial planning theories focused on form seemed to match up with other practices and goals, including regional transportation and environmental protection (for a detailed discussion of the GMA's goals and major legal strategies see Chapter 36.70a.020 of the Regulatory Code of Washington at https://app. leg.wa.gov/rcw/default.aspx?cite=36.70a.020). This partially explains their popularity with a local planning profession looking urgently for extra-local ideas to advance coordination issues within and between communities.

As new spaces of New Urbanism emerged in and around Seattle, however, they were embedded within extant geographies of what Desmond King and Rogers Smith (2005, p. 75) have called contending "racial orders in American political development." Central to King and Smith's argument is that American politics has been long constituted by two evolving but linked racial institutional orders: a set of white supremacist orders and a competing set of transformative egalitarian orders. While they may involve contending coalitions of actors and institutions inside and outside the state, at different times individuals can occupy both at the same time, as Franklin Roosevelt did, and shifts from one to another are not linear but wax and wane as cycles of regression and progression. Racial orders are, of course, spatial formations, an underdeveloped theme in APD scholarship, although Ira Katznelson's (1981) early APD tome, City Trenches, broadly explained what he called the "politics of community" (rather than the politics of work) around race, ethnicity, and territory (as opposed to class conflicts in labor markets).

Greenfield sites, where New Urbanism is most completely imagined and pragmatically implemented, were not open spaces at all, free from these deeper and wider orders. Neither, of course, were core areas of concentrated poverty in cities like Seattle or Tacoma, where HOPE VI public housing programs associated strongly with New Urbanist design theories have remade key residential landscapes (Deitrick \& Ellis, 2004). New Urbanism's impacts on select greenfield developments in suburban areas of the Seattle city-region, which again includes the nearby city of Tacoma and Pierce County, provide opportunities to consider its intersections with these two contending racial orders. Two major New Urbanist applications, Snoqualmie Ridge, in King County near Seattle, and Northwest Landing, in Pierce County near Tacoma, illustrate the diversity of territorial outcomes, and how, I argue, these outcomes might be better understood in relation to racial institutional orders (Figure 2).

Comparative densities in the Greater Seattle region include 7,250 people/mile in the city of Seattle; 3,990 in 
the city of Tacoma, the region's second city; and 3,827 in Bellevue, the region's leading edge city. In 2019, the densities in Dupont and Snoqualmie were 1,399 and 1,666 , respectively, which are consistent with suburban patterns seen elsewhere in the region. That said, Snoqualmie Ridge and Northwest Landing are large-scale New Urbanist extensions of older villages 'pulled into' post-metropolitan development pressures. Both communities date to the early 1990s.

\subsection{Suburban New Urbanism: Comparing Snoqualmie Ridge with Northwest Landing}

Snoqualmie Ridge, a 526-hectare master planned community in the small municipality of Snoqualmie, is located in the majestic and highly desirable foothills of the Cascade Mountains about 40 kilometers due east of Seattle. The municipality of Snoqualmie was founded in the 1890s, and thus has developed from a small, rural hamlet into a high-tech commuter suburb. Along with 'Issaquah Highlands' and 'Redmond Ridge' (near the cam- pus home of Microsoft), 'Snoqualmie Ridge' was (and is) one of three major New Urbanist projects in fastgrowing King County, the home of Seattle, that has been shaped strongly by the 'high-tech' property boom of the late 20th century (Dierwechter, 2017). Within easy commuting range of high-tech edge cities like Redmond and Bellevue, Snoqualmie Ridge quickly attracted wealthy families who wanted "to be out of city life, but close to city attractions" (McKenzie, 2012). Like Howard's garden city promises flouted more than a century ago, melding urban and rural amenities and imaginaries remains a powerful discourse.

Northwest Landing, in contrast, is the most prominent New Urbanist-inspired greenfield development in Pierce County, where growth pressures are less associated with high-tech restructuring but instead the impact of the nearby army and air force military bases (Figure 2). While Snoqualmie Ridge's population is $00.08 \%$ African American, Northwest Landing's African-American population is $14.10 \%$, which is not only much higher than most suburbs in the Seattle metropolitan region, but also

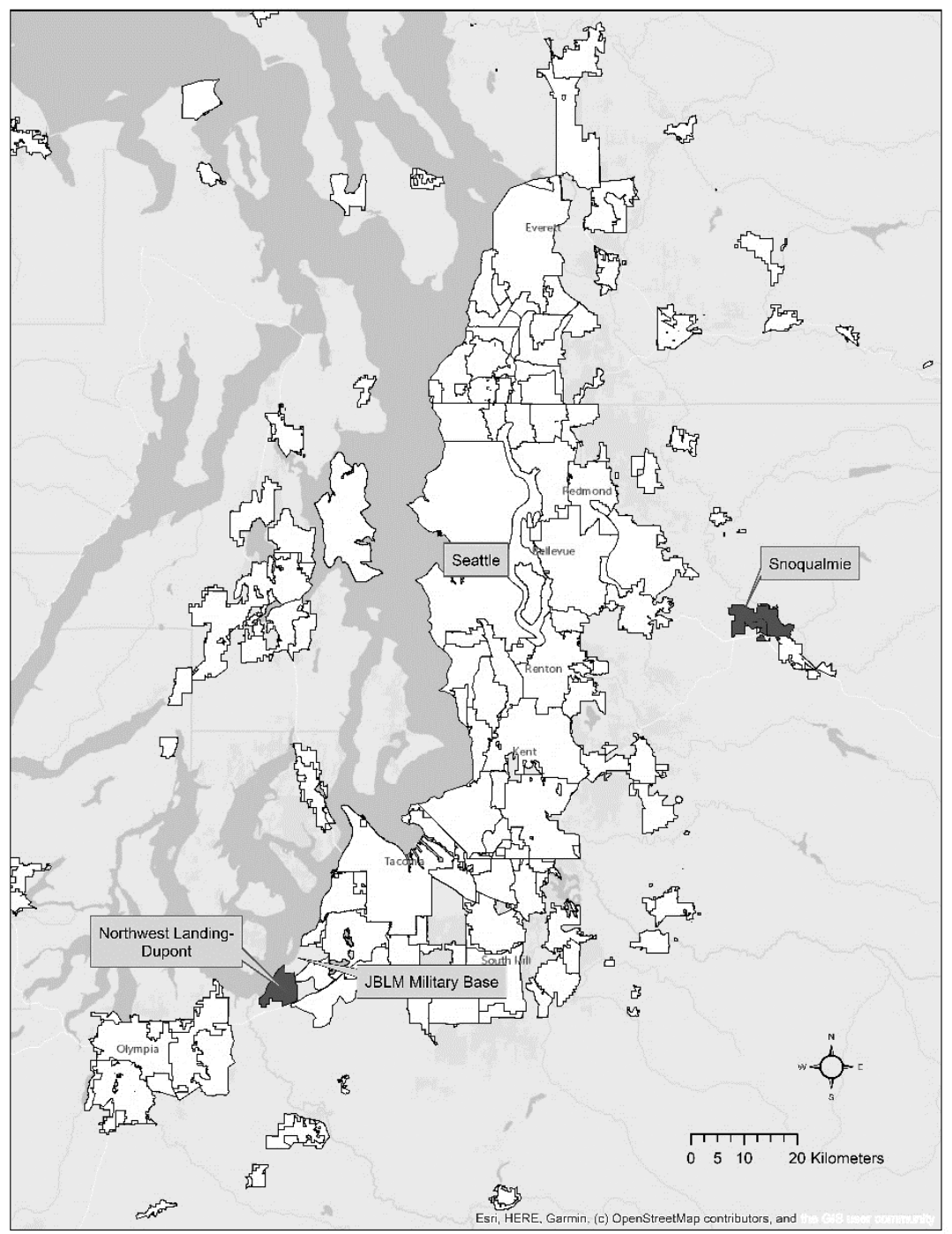

Figure 2. New Urbanist case studies in city-regional context. Source: Author. 
much higher than found in the city of Seattle, where recent processes of urban inversion and gentrification have extruded much of the city's black population (Balk, 2014; Gibson, 2004). Superficially, Northwest Landing is just a bigger version of Snoqualmie Ridge. Conceived originally by Peter Calthorpe, Northwest Landing is 1,200-hectare master planned community with similarly tree-lined streets shaped aesthetically by "housing types [that] reflect the distinct [N]orthwest cottage style and complement contextual urbanism such as Dupont's charming tree-lined streets or its distinctive Craftsman-style architecture" (Calthorpe, 2020). Like Snoqualmie Ridge, moreover, Northwest Landing is a massive 'extension' of this older village-Dupontwhich, like Snoqualmie, was founded much earlier than its adjacent suburbs.

Yet significant differences are important. Northwest Landing has greater residential diversity; $54 \%$ of homes are owner-occupied whereas the figure is $85 \%$ for Snoqualmie Ridge, where median home values are about $85 \%$ higher than in Northwest Landing. In addition, more than $25 \%$ of Dupont's firms are minority-owned; the figure for Snoqualmie remains well under 1\%. Marking places as highly educated, super expensive, overwhelming white residential and business space redesigned around neo-traditional forms of the urban village is another way of talking about the urban geographies of metropolitan America that help to reproduce ongoing institutions of white privilege; this links "spatial forms" with Harvey's (1997) aforementioned concerns around "social processes" that involve race and class as they interact with post-Fordist economic restructuring in the Seattle city-region.

Northwest Landing's better social performance can be attributed, in contrast, to the 'transformative egalitarian' racial order associated with minority mobility experienced in the military, in general, and the racial composition of Joint-Base Lewis-McCord (JBLM) located just north of Dupont, in particular. According to the US Census Bureau (2019), JBLM was about $60 \%$ white and over $20 \%$ African American in 2019. A detailed analysis of racial dynamics, experiences, incomes, and career opportunities within the US military-the say nothing of the 'militarized state' more generally-falls well beyond this article; yet JBLM's current racial composition, particularly with respect to African Americans, reflects the early role of the armed forces in advancing the politics of desegregation starting with the Truman administration. Active duty and retired military personnel at JBLM shape the social and economic geographies of adjacent Northwest Landing in rather different ways than found in the New Urbanist spaces of high-tech King County, Snoqualmie Ridge included. Essentializing New Urbanist greenfields as "suburbs in disguise" therefore requires us, following Trudeau and Molloy (2011), to explore not only the metropolitan spaces of this aspatial critique, but the ways in which New Urbanist geographies relate to intercurrence with other orders, including con- tending racial institutional orders that have long shaped American society and its spatial problems.

\subsection{New Urbanism within Seattle}

Contending "racial institutional orders" are even clearer when we scale down from the wider city-region to the core municipality of Seattle. In addition to the overall growth and economic restructuring briefly discussed above, Seattle's class structures have significantly shifted in recent years. Seattle exemplifies the divergence of household wages between and within places, worsening the effects of what Dreier, Mollenkopf, and Swanstrom (2014) call the "economic segregation" of the US. The tech-driven industrial clustering around Microsoft and Amazon also discussed earlier has benefitted high-skilled workers. More of Seattle's overall population is made up of well-educated households earning $\$ 100,000$ year or more-and especially households earning $150-\$ 200,000$ or more. At the same time, middleclass households make up less and less of Seattle's overall social structure.

Drawing on design and urban form principles associated with both New Urbanism and Smart Growth, since the early 1990s Seattle has pursued a high-profile strategy of urban sustainability constantly focused on building urban centers and 'villages' through mixed-use densification and new connections forged across the city and region by light rail alternatives to automobiledependence (City of Seattle, 1994). What are the results? How do these planning dynamics intersect especially with contending racial institutional orders?

Examples of Seattle's long-running efforts to build an transformative egalitarian racial order are easy enough to mobilize. In 1941, the Seattle Housing Authority built Yestler Terrace, the first racially integrated public housing development in the US. In 1990, Norm Rice was elected Seattle's first black mayor. More recently, the city's Equitable Justice Delivery System has sought to embed race and social justice and service equity across Seattle's public utility services, placing 'environmental justice' at the core of the city's wider equity goals; thus, Seattle's staff use an "Equity Planning Toolkit" to engage in outreach activities (Seattle Public Utilities, 2019).

Yet once again, African American communities are shrinking as a proportion of the city's overall population (down to less than 7\%, compared with, for example, $24 \%$ in high-tech Boston). The historic Central District in Seattle was about $80 \%$ African American in the 1970 s. By 2010 , it was a majority white neighborhood; racial transformation has only accelerated since then. Seattle has become even richer as high-tech capital flows into local and regional labour markets, but the city's remaining black households are getting relatively poorer (Balk, 2014). Like its West Coast rival, San Francisco, Seattle is less an emerald city than an elite emerald. New urban efforts to build smarter, connected, more sustainable, urban centers and villages are engines of in situ social 
displacement and even a certain measure of racial purification, all of which deeply concerns a city long associated with egalitarian environmental and racial policy commitments.

At the same time, the City of Seattle (2016) has developed an "Equitable Development Implementation Plan" as a detailed and focused compliment to New Urbanist planning and smart growth development policies. The Puget Sound Regional Council, the region's metropolitan planning organization, and Sound Transit, Seattle's regional transit agency, have additionally focused on equitable transit-oriented development strategies, in part as a response to state legislation enacted in 2015 to address social displacement and growing inequality (Sound Transit, 2018). New projects include partnerships with non-profit groups like Puget Sound Sage, which has worked with Sound Transit in recent years to alleviate better the growing displacement effects of traditional TOD investments, arguing that "in-movers own cars at high rates" while "low-earning residents use transit more frequently to get to work" (Puget Sound Sage, 2012, p. iv). In contrast to recent strategies in places like Minneapolis that have upzoned nearly everywhere to try to promote greater racial inclusion through residential density, Seattle elected originally-and still elects-to channel new growth into a targeted geography of select spaces that mix residential and commercial activities. Locally, this strategy has aimed from the start to protect $70 \%$ of the city from development through the legal shield of singlefamily zoning, a decision bemoaned by many activists (Beekman, 2019).

\section{Conclusions}

The geographical diffusion of New Urbanism in the Seattle city-region was aided by the political development of spatial planning under the GMA of 1991/92, when the State of Washington confronted fiscal, environmental, and social inadequacies in how local communities (mis)managed urban growth. Seeing New Urbanism as UPD, however, draws theoretical attention to what APD scholars call 'intercurrence,' or multiple-orders-inaction, including, I have argued here, contending racial orders. Like Smart Growth and sustainable development, New Urbanism seemed to "square the circle" (Herrschel, 2013, p. 2332), offering city transformation through reinforcing, even restoring, older forms of urban development and imagined social life. Yet it also encountered a 'thickly' institutionalized world of prior construction shaped by race and class.

The GMA system in Washington mixed long-standing theories of planning, notably the rationality of the mandated comprehensive plan and 'ancient' Constitutional discourses around property rights through state power, with newer ecological concerns around regulating critical areas and the pragmatic design ideals of New Urbanism. Within Seattle, comprehensive planning has selectively spatialized New Urbanism, applying it outside the larger swaths of modernism where mixed-use and transit urbanism confront the durable legacies of Euclidean zoning regimes largely in place since the 1930s, legacies that insinuate themselves in new controversies. These new controversies implicate ongoing political tensions associated with the intercurrence of wider racial institutional orders in the US. While New Urbanism in the Snoqualmie case study subtly (if not explicitly) reinforces metropolitan geographies of white privilege, I have also argued, it has helped to challenge these same geographies in Northwest Landing, interacting with the nearby military's transformative egalitarian order in ways that add new readings of New Urbanist forms of spatial development.

Other analytical readings of New Urbanism which emphasize, with Marxians for instance, the role of planning theories and practices in facilitating capital accumulation or, with post-structuralists, rationalizing the territorial exercise of power offer alternatives to urban APD scholarship. Seeing New Urbanism with neo-Weberian institutionalists as a state-led form of UPD, however, draws needed attention to the concomitant operation of multiple orders of variegated political times. I think there is value in that for planning scholars that seek to better understand how leading theories 'land' across diverse communities in particular places, including the Seattle city-region. At the same time, importing APD concepts like intercurrence into spatial disciplines like planning, urban design, and geography offers new opportunities for APD. Like many fields, as Ed Soja (1989) repeatedly argued, APD scholars are more interested in time than space, in institutions than spatialities. Intercurrence, though, is hardly aspatial; how it works is partly a function of its spatial formations. Mapping the uneven geographies of New Urbanism tells us something about the spatialities of political development itself that are, frankly, under-explored in most political science literature.

Much more comparative work is needed, however, at the metropolitan scale of analysis, where the heterogeneous spatialities of New Urbanism, and other planning movements, are brought into different conversations with wider theories of social and political development. While New Urbanism might help to reinforce racialized geographies of white privilege and supremacy in some communities, it may well advance racial egalitarian orders in still others. Understanding where these dynamics occur is an important part of understanding why they occur-and thus what we can reasonably expect of New Urbanism as a normative theory of placemaking. At a tumultuous time when the political development of the US is struggling (once again) with core questions of race-with Black Lives Matter vs. white ethnic nationalism -it seems patently obvious that new ways of thinking about racial orders are imperative in American planning studies. At the same time, problems of race are, of course, global challenges, as are problems of sprawl, auto-dependency, and ecological decay. As APD 
and New Urbanism steadily leave the parochial shores of (North) America, far more cosmopolitan insights await both fields, particularly if they can be brought into sustained dialogue with one another.

\section{Acknowledgments}

Special thanks to Brian Coffey and Charles Williams (University of Washington, Tacoma) as well as Byron Miller, Jack Lucas, and Elliot Tretter (University of Calgary) for various forms of assistance, known and unknown, at different stages of reflection and research. Thanks also to the Fulbright U.S. Scholar Program in Canada for supporting my research project 'Making Smart Growth Smarter' while serving as a visiting scholar at the University of Calgary in 2019.

\section{Conflict of Interests}

The author declares no conflict of interests.

\section{References}

Balk, G. (2014, November 12). As Seattle gets richer, the city's black households get poorer. Seattle Times. Retrieved from https://www.seattletimes.com/ news/as-seattle-gets-richer-the-citys-blackhouseholds-get-poorer-2

Beekman, D. (2019, March 18). Seattle upzones 27 neighborhood hubs, passes affordable-housing requirements. Seattle Times. Retrieved from https:// www.seattletimes.com/seattle-news/politics/ seattle-upzones-27-neighborhood-hubs-passesaffordable-housing-requirements

Calthorpe, P. (2020). Northwest Landing. Calthorpe. Retrieved from https://www.calthorpe.com/ northwest-landing

City of Seattle. (1994). Comprehensive plan: Towards a sustainable Seattle. Seattle, WA: Office of Management and Planning.

City of Seattle. (2016). Equitable development implementation plan: April 2016. Seattle, WA: Office of Planning \& Community Development. Retrieved from https://www.seattle.gov/Documents/Departments/ OPCD/OngoingInitiatives/SeattlesComprehensive Plan/EDIImpPlan042916final.pdf

Crane, R. (1996). On form versus function: Will the new urbanism reduce traffic, or increase it? Journal of Planning Education and Research, 15(2), 117-126.

De Villiers, P. (1997). New urbanism: A critical review. Australian Planner, 34(1), 30-34.

Deitrick, S., \& Ellis, C. (2004). New Urbanism in the inner city. Journal of the American Planning Association, $70,426-442$

Dierwechter, Y. (2008). Urban growth management and its discontents: Promises, practices and geopolitics in US city-regions. New York, NY: Palgrave.

Dierwechter, Y. (2013). Smart growth and state territori- ality. Urban Studies, 50(11), 2275-2292.

Dierwechter, Y. (2014). The spaces that Smart Growth makes: Sustainability, segregation, and residential change across Greater Seattle. Urban Geography, 35(5), 691-714.

Dierwechter, Y. (2017). Urban sustainability through smart growth: intercurrence, planning, and the geographies of regional development across Greater Seattle. Cham: Springer.

Dierwechter, Y. (2020). Urban sustainability through suburban growth? Smart regional planning in the Pacific Northwest. In B. Garren \& R. Brinkmann (Eds.), Case studies in suburban sustainability (pp. 49-66). Gainesville, FL: University of Florida Press.

Dierwechter, Y., \& Coffey, B. (2017). The travels, triumphs and travails of new urbanism: Representational geographies in US newspapers, 1990-2012. Journal of Urbanism: International Research on Placemaking and Urban Sustainability, 10(4), 385-400.

Dilworth, R. (Ed.). (2009). The city in American political development. New York, NY: Routledge.

Dilworth, R. (2016). Cities and urbanization in American political development. In R. Valelly, S. Mettler, \& R. Lieberman (Eds.), The Oxford handbook of American political development (pp. 381-396). Oxford: Oxford University Press.

Dilworth, R., \& Weaver, T. (Eds.). (2020). How ideas shape urban political development. Philadelphia, PA: University of Pennsylvania Press.

Dreier, P., Mollenkopf, J. H., \& Swanstrom, T. (2014). Place matters: Metropolitics for the twenty-first century (3rd ed.). Lawrence, KS: University Press of Kansas.

Durham-Jones, E. (2000). New urbanism as counterproject to post-industrialism. Places-a Forum of Environmental Design, 13(2), 26-31.

Ellis, C. (2002). The New Urbanism: Critiques and rebuttals. Journal of Urban Design, 7, 261-291.

Evans, P. B., Rueschemeyer, D., \& Skocpol, T. (1985). Bringing the state back in. Cambridge and New York, NY: Cambridge University Press.

Fainstein, S. (2000). New directions in planning theory. Urban Affairs Review, 35(4), 451-478.

Flyvbjerg, B. (1998). Rationality and power: Democracy in practice. Chicago, IL: University of Chicago Press.

Foglesong, R. (1986). Planning the capitalist city: The colonial era to the 1920s. Princeton, NJ: Princeton University Press.

Forrest, R., \& Wissink, B. (2017). Whose city now? Urban managerialism reconsidered (again). The Sociological Review, 65(2), 155-167.

Garde, A. M. (2004). New Urbanism as sustainable growth? Journal of Planning Education and Research, 24(2), 154-170.

Gibson, T. A. (2004). Securing the spectacular city: The politics of revitalization and homelessness in downtown Seattle. Lanham, MD: Lexington Books.

Grant, J. (2006). Planning the good community: New 
Urbanism in theory and practice. London and New York, NY: Routledge

Grant, J. (2007). Two sides of a coin? New Urbanism and gated communities. Housing Policy Debate, 18, 481-501.

Gray, M., Golob, E., \& Markusen, A. (1996). Big firms, long arms, wide shoulders: The 'hub-and-spoke' industrial district in the Seattle region. Regional Studies, 30(7), 651-666.

Gurr, T., \& King, D. (1987). The state and the city. London: Macmillan.

Harvey, D. (1997). The New Urbanism and the communitarian trap. Harvard Design Magazine, 1997(Spring), 1-3.

Herrschel, T. (2013). Competitiveness and sustainability: Can 'smart city regionalism' square the circle? Urban Studies, 50(11), 2332-2348.

Herrschel, T., \& Dierwechter, Y. (2018). Smart transitions in city-regionalism: The quest for competitiveness and sustainability. London: Routledge.

Hodos, J. (2009). Against expectionalism: Intercurrence and intergovernmental relations in Britain and the United States. In R. Dilworth (Ed.), The city in American political development (pp. 44-63). New York, NY: Routledge.

Hooper, P., Foster, S., Knuiman, M., \& Giles-Corti, B. (2018). Testing the impact of a planning policy based on new urbanist planning principles on residents' sense of community and mental health in Perth, Western Australia. Environment and Behavior, 52(3), 305-339.

Hoyland, K. (2003). New Urbanism as a factor in the mobility of the elderly. In R. García Mira, S. Cameselle, J. Manuel, \& J. Romay Martínez (Eds.), Culture, environmental action, and sustainability (pp. 351-365). Cambridge, MA: Hogrefe \& Huber.

Jones, M. R. (1997). Spatial selectivity of the state? The regulationist enigma and local struggles over economic governance. Environment and Planning $A$ : Economy and Space, 29(5), 831-864.

Katznelson, I. (1981). City trenches: Urban politics and the patterning of class in the United States. New York, NY: Pantheon Books.

King, D. S., \& Smith, R. M. (2005). Racial orders in American political development. American Political Science Review, 99(1), 75-92.

Knaap, G., \& Talen, E. (2005). New Urbanism and smart growth: A few words from the academy. International Regional Science Review, 28(2), 107-118.

Kushner, J. (2003). Smart growth, New Urbanism and diversity: Progressive planning movements in America and their impact on poor and minority ethnic populations. UCLA Journal of Environmental Law \& Policy, 21(1), 45.

Larsen, K. (2005). New Urbanism's role in inner-city neighborhood revitalization. Housing Studies, 20(5), 795-813.

Lucas, J. (2017). Urban governance and the Ameri- can political development approach. Urban Affairs Review, 53(2), 338-361.

MacLeod, G. (2013). New urbanism/smart growth in the Scottish highlands: Mobile policies and post-politics in local development planning. Urban Studies, 50(11) 2196-2221.

Marks, G., \& Lipset, S. M. (2000). It didn't happen here: Why socialism failed in the United States. New York, NY: W.W. Norton.

McKenzie, M. (2012, January 12). Neighborhood of the week: Snoqualmie Ridge. Seattle Times. Retrieved from https://www.seattletimes.com/business/realestate/neighborhood-of-the-week-snoqualmieridge

Mitchell, T. (2002). Going whole hog for new urbanism. Planning, 68(2), 28.

Moore, S. (2010). 'More Toronto, naturally' but 'too strange for Orangeville': De-universalizing New Urbanism in Greater Toronto. Cities, 27(2), 103-113.

Murray, M. (2013). The quandary of post-public space: New Urbanism, Melrose Arch and the rebuilding of Johannesburg after Apartheid. Journal of Urban Design, 18(1), 119-144.

O'Toole, R. (2007). Best-laid plans: How government planning harms your quality of life, your pocketbook, and your future. Washington, DC: Cato Institute.

Pahl, R. (1970). Whose city? and other essays on sociology and planning. London: Longman.

Puget Sound Regional Council. (2008). The Washington state growth management act. Seattle, WA: Puget Sound Regional Council.

Puget Sound Sage. (2012). Ensuring transit investment in Seattle's rainier valley: Build communities where all families thrive. Seattle, WA: Puget Sound Sage.

Rast, J. (2015). Urban regime theory and the problem of change. Urban Affairs Review, 51(1), 138-149.

Rees, A. (2017). New Urbanism. In B. Turner (Ed.), The Wiley-Blackwell encyclopedia of social theory (pp. 1-5). Oxford: John Wiley \& Sons.

Robinson, L., Newell, J. P., \& Marzluff, J. M. (2005). Twenty-five years of sprawl in the Seattle region: Growth management responses and implications for conservation. Landscape and Urban Planning, 71(1), 51-72.

Seattle Public Utilities. (2019). SPU equity planning toolkit: Stakeholder analysis. Seattle, WA: Seattle Public Utilities. Retrieved from https://www. seattle.gov/Documents/Departments/SPU// EquityPlanningTools.pdf

Skowronek, S., \& Orren, K. (2004). The search for American political development. Cambridge and New York, NY: Cambridge University Press.

Smith, R. M. (1993). Beyond Tocqueville, Myrdal, and Hartz: The multiple traditions in America. The American Political Science Review, 87(3), 549-566.

Soja, E. (1989). Postmodern geographies: The reassertion of space in critical social theory. London and New York, NY: Verso. 
Sound Transit. (2018). Resolution No. R2018-10: Adopting an equitable transit oriented development policy. Seattle, WA: Sound Transit. Retrieved from https://www.soundtransit.org/st_sharepoint/ download/sites/PRDA/FinalRecords/2018/ Resolution\%20R2018-10.pdf

St. Antoine, T. (2007). Making heaven out of hell: New Urbanism and the refutation of suburban spaces. Southern Communication Journal, 72(2), 127-144.

Steuteville, R. (2008). Directory of the New Urbanism. Ithaca, NY: New Urban News Publications.

Stone, C. (2015). Reflections on regime politics: From governing coalition to urban political order. Urban Affairs Review, 51(1), 101-137.

Talen, E. (2000). New Urbanism and the culture of criticism. Urban Geography, 21, 318-341.

Talen, E. (2005). New Urbanism and American planning: The conflicts of cultures. London and New York, NY: Routledge.

Talen, E., \& Ellis, C. (2002). Beyond relativism: Reclaiming the search for good city form. Journal of Planning Education and Research, 22(1), 36-49.

Trudeau, D. (2013a). New Urbanism as sustainable development? Geography Compass, 7(6), 435-448.

Trudeau, D. (2013b). A typology of New Urbanism neighborhoods. Journal of Urbanism, 6(2), 113-138.

Trudeau, D., \& Molloy, P. (2011). Suburbs in disguise? Geographies of New Urbanism. Urban Geography, 32(3), 424-447.

U.S. Census Bureau. (2018). Quickfacts: Snoqualmie city,
Washington. U.S. Census Bureau. Retrieved from https://www.census.gov/quickfacts/

snoqualmiecitywashington

U.S. Census Bureau. (2019). Quickfacts: Fort Lewis CDP, Washington. U.S. Census Bureau. Retrieved from https://www.census.gov/quickfacts/fact/map/ fortlewiscdpwashington, US/PST045219

Valelly, R. M., Mettler, S., Lieberman, R. C., Valelly, R. M., Mettler, S., \& Lieberman, R. C. (2016). The Oxford handbook of American political development. Oxford: Oxford University Press.

Vanderbeek, M., \& Irazábal, C. (2007). New Urbanism as a new Modernist movement: A comparative look at Modernism and New Urbanism. Traditional Dwellings and Settlements Review, 19(1), 41-57.

Washington City Planners Director Association. (1989). Towards a growth strategy for Washington. Olympia, WA: Association of Washington Cities.

Whittemore, A. (2015). Practitioners theorize, too: Reaffirming planning theory in a survey of practitioners' theories. Journal of Planning Education and Research, 35(1), 76-85.

Widestrom, A. (2011). The political development of public policy: Institutions, intercurrence, and the community reinvestment act. Paper presented at the Western Political Science Association 2011 Annual Meeting, San Antonio, TX, USA.

Yiftachel, O. (1989). Towards a new typology of urban planning theories. Environment and Planning B: Planning and Design, 16(1), 23-39.

\section{About the Author}

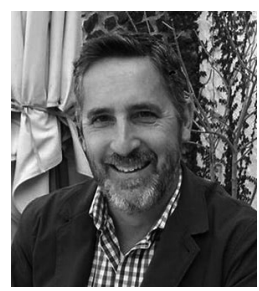

Yonn Dierwechter is Professor in the School of Urban Studies at the University of Washington, Tacoma, USA. He earned his PhD from the Department of Geography and Environment at the London School of Economics. His research focuses on emerging relationships between spatial planning systems, urban political geography, and global sustainability, including a forthcoming book with Anthem Press entitled Climate Change and the Future of Seattle. 